\title{
Preliminary evaluation of the effect of juvenile hormone III and methyl farnesoate on spermatophore quality of the white shrimp, Litopenaeus vannamei Boone, 1931 (Decapoda: Penaeidae)
}

\author{
Evaluación preliminar del efecto de la hormona juvenil III y del metil farnesoato en la calidad \\ de espermatóforos del camarón blanco, Litopenaeus vannamei \\ Boone, 1931 (Decapoda: Penaeidae) \\ Jorge Alfaroํㅜ Gerardo Zúñiga ${ }^{1}$, Andrea García ${ }^{1}$ and Ericka Rojas ${ }^{1}$ \\ ${ }^{1}$ Estación de Biología Marina, Escuela de Ciencias Biológicas, Universidad Nacional, Puntarenas,Costa Rica \\ jalfarom@una.ac.cr
}

\begin{abstract}
Resumen.- Este estudio preliminar es un primer paso en la exploración del efecto de la hormona juvenil III (HJ III) y el metil farnesoato (MF) sobre la calidad de espermatóforos de Litopenaeus vannamei. La HJ III aplicada cinco veces a una dosis de $109 \mathrm{ng} \mathrm{g}^{-1}$ de peso corporal (p.c.) durante 58 días, no mejoró el conteo de espermatozoides en comparación con el grupo control $(P>0,05)$. La anormalidad de espermatozoides disminuyó en las regeneraciones sucesivas de espermatóforos de manera similar en machos tratados con $\mathrm{HJ}$ y machos control
\end{abstract}

$(P>0,05)$. Por el contrario, un total de cinco aplicaciones semanales de MF a $120 \mathrm{ng} \mathrm{g}^{-1}$ p.c. causó un incremento significativo en número de espermatozoides y una disminución en anormalidad de espermatozoides $(P<0,05)$. Una dosis mayor de MF (1200 ng g $\mathrm{g}^{-1}$ p.c.) no causó un efecto significativo sobre la calidad de los espermatóforos $(P>0,05)$.

Palabras clave: Camarones penaeoideos, Dendrobranchiata, hormona juvenil, metil farnesoato, reproducción

\section{Introduction}

Reproduction facilities based on pond-grown animals require males that generate acceptable levels of high quality sperm. Males from earthen ponds, regardless of size, show low sperm levels and high rates of abnormal sperm (Leung-Trujillo \& Lawrence 1985, Alfaro \& Lozano 1993, Alfaro 2001, Ceballos-Vásquez et al. 2003).

Juvenile hormones (JH 0, I, II, III) play a major role in controlling larval development, stimulating vitellogenin synthesis, and controlling female reproductive development in Insecta (Downer \& Laufer 1983). As in insects, methyl farnesoate (MF, unepoxidated precursor of JH III), synthesized and secreted by the mandibular organ in crustaceans, seems to stimulate reproduction in both males and females acting as a gonadotropin and also a morphogen (Laufer et al. 1988, Homola et al. 1991, Rotllant et al. 2000, Laufer \& Biggers 2001).

The function of juvenile hormone-like compounds in crustaceans has been subject to debate (Wilder et al. 1995, Homola \& Chang 1997, Abdu et al. 2001); in Procambarus clarkii Girard 1852 and Libinia emarginata Leach 1815, MF elevations stimulate ovarian maturation
(Laufer et al. 1998, Que-Tae et al. 1999); however, in Cherax quadricarinatus Martens, 1868 there is no effect on female reproduction (Abdu et al. 2001). In $L$. emarginata, there are different male morphotypes and their reproductive behavior and the reproductive system development are associated with different levels of MF in the hemolymph (10.7 to $67.2 \mathrm{ng} \mathrm{mL}^{-1}$; Homola et al. 1991, Sagi et al. 1993). In Penaeus japonicus Bate 1888, $\mathrm{JH}$ and MF were not detected in males, immature females, nor maturing females (Wilder \& Aida 1995). However, MF has been identified in other penaeoid shrimps, including Litopenaeus vannamei Boone, 1931 and $L$. stylirostris Stimpson, 1874 (Laufer \& Biggers 2001). In L. vannamei, JH III and MF significantly increased the diameter of late perinucleolus stage oocytes from isolated immature ovaries (Tsukimura \& Kamemoto 1991). Fecundity in L. vannamei was increased by MF, probably as an indirect result of Y-organ stimulation to synthesize and secrete ecdysteroids, which accumulate in the ovaries (Laufer 1992, Laufer et al. 1997).

No study has been published on the role that juvenoids may play on spermatophore quality of penaeoid shrimps; therefore, this is a preliminary study designed to explore the possible effect of JH III and MF injection on spermatophore quality of L. vannamei. 


\section{Material and methods}

\section{JH III experiment}

Ten young males (b.w. $=23.0 \pm 2.8 \mathrm{~g}$ ) were stocked in an $18 \mathrm{~m}^{2}$ maturation tank at Estación de Biología Marina, Puntarenas, Costa Rica. Water exchange was kept at 20\% per day; salinity was $32 \mathrm{ppt}$ and temperature was maintained at $28^{\circ} \mathrm{C}$. Photoperiod was natural $(13 \mathrm{~h}$ light: $11 \mathrm{~h}$ dark), with reduced light intensity $(10-43$ lux $)$. Animals were fed at $1.6 \%$ b.w. of a dry commercial feed plus fresh frozen sardine and squid at $4 \%$ b.w., and acclimatized for one week. Males were randomly assigned to two treatments: a) JH III injection $(n=5)$, and b) control group $(n=5)$.

JH III was prepared by dissolving the hormone (Sigma Co.) in ethanol to $2.5 \mathrm{mg} \mathrm{mL}^{-1}$. A working solution was then prepared by diluting $0.10 \mathrm{~mL}$ of the concentrated stock to $10 \mathrm{~mL}$ of sterile saline solution $(0.85 \% \mathrm{NaCl})$, and kept under refrigeration during the experimental period. Males were injected laterally in the second abdominal segment with $0.10 \mathrm{~mL}$ ( $2500 \mathrm{ng}$ of JH III) to give a dose of $109 \mathrm{ng} \mathrm{g}^{-1}$ b.w., at days 1, 9, 30, 43, and 58 . Control males received $0.10 \mathrm{~mL}$ of the vehicle solution $(0.10 \mathrm{~mL}$ ethanol to $10 \mathrm{~mL}$ saline solution), administered the same days.

Spermatophores were manually ejaculated at days 8 , $29,42,57$, and 70, and analyzed for sperm count, and percentage of abnormal sperm, as previously described (Alfaro \& Lozano 1993). Measurements were repeated three times for each male.

\section{MF experiment}

Twenty males (b.w. $=27.5 \pm 2.1 \mathrm{~g}$ ) were stocked in an $18-\mathrm{m}^{2}$ maturation tank. Culture conditions were similar to the first experiment, and animals were fed at $15 \%$ b.w. with fresh frozen sardine and squid (1:1). Two males were used for baseline spermatophore condition at initiation, and the other males were randomly assigned to three treatments: a) control group $(\mathrm{n}=6), \mathrm{b}) \mathrm{MF}$ injection at $120 \mathrm{ng} \mathrm{g}^{-1}$ b.w. $(\mathrm{n}=6)$, and c) MF injection at $1200 \mathrm{ng} \mathrm{g}$ ${ }^{1}$ b.w. $(\mathrm{n}=6)$.

MF was prepared by dissolving the hormone (Echelon Biosciences Inc.) in ethanol to $10 \mathrm{mg} \mathrm{mL}^{-1}$. MF at $120 \mathrm{ng}$ $\mathrm{g}^{-1}$ was then prepared by diluting $0.07 \mathrm{~mL}$ of the concentrated stock to $10 \mathrm{~mL}$ of ethanol, and injecting $0.05 \mathrm{~mL}$. MF at $1200 \mathrm{ng} \mathrm{g}^{-1}$ was prepared by diluting 0.7 $\mathrm{mL}$ of the stock solution to $10 \mathrm{~mL}$ ethanol, and injecting $0.05 \mathrm{~mL}$. Solutions were kept at $-10^{\circ} \mathrm{C}$ during the experimental period. Males were injected laterally in the second abdominal segment at days 1, 8, 15, 22, and 29. Control males received $0.05 \mathrm{~mL}$ of the vehicle solution (ethanol), administered the same days. Analysis of spermatophores was performed on day 36 as indicated in the previous experiment; successive ejaculations were not performed to exclude this quality enhancing factor as it was observed in the $\mathrm{JH}$ experiment.

\section{Statistical Analyses}

Data on sperm count and sperm abnormalities were transformed using squared root of $Y+3 / 8$ and arcsine of squared root of $\mathrm{Y}$, respectively, to make the variance independent of the mean (Ott 1984). Transformed data from the $\mathrm{JH}$ experiment were analyzed with 2-sample $\mathrm{t}$ test at $\alpha=0.05$ (Ott 1984), comparing mean values between treatments at each successive ejaculation. Complementary, mean values within treatments were compared at first and last ejaculation using paired t test at $\alpha=0.05$ (Ott 1984). Transformed sperm counts and abnormalities from the MF experiment were analyzed with one way analysis of variance and Tukey's w procedure at $\alpha=0.05$ (Ott 1984). Statistical analyses were performed with Minitab program. Figures present untransformed data as mean values \pm standard deviation.

\section{Results}

Mortality was very low for the JH experiment; being $1 / 5$ and $0 / 5$ for $\mathrm{JH}$ and control group, respectively. The control group (Fig. 1) showed an increase in sperm count in successive regenerations, reaching an average of 18 and 17 million sperm per compound spermatophore at ejaculation 4 (day 57) and 5 (day 70), respectively. Sperm count at day 70 was statistically higher than at day 8 $(P<0.05)$. The standard deviation lines, for the control group, indicate an increased variability between replicates as the study progresses. On the other hand, JH III-injected males at $109 \mathrm{ng} \mathrm{g}^{-1}$ b.w. experienced a low or no sperm improvement in successive regenerations; no statistical differences were detected between day 8 and $70(P>0.05)$. The high variability measured for the control group did not allow detecting significant differences between treatments $(P>0.05)$.

In successive spermatophore regenerations, sperm abnormalities (Fig. 1) decreased at a similar rate between treatments. Control males with abnormalities around $60 \%$ at first ejaculation, decreased to $46 \%$ at fifth regeneration, and $\mathrm{JH}$ treated males reduced abnormalities from $80 \%$ (ejaculation 1) to $50 \%$ (ejaculation 5). No statistical differences were detected between treatments at each ejaculation $(P>0.05)$.

MF was tested at two doses, with five injections being applied weekly (Fig. 2). Mortality was 3/6 for control and MF 1200 treatments, and 2/6 for MF 120. This 

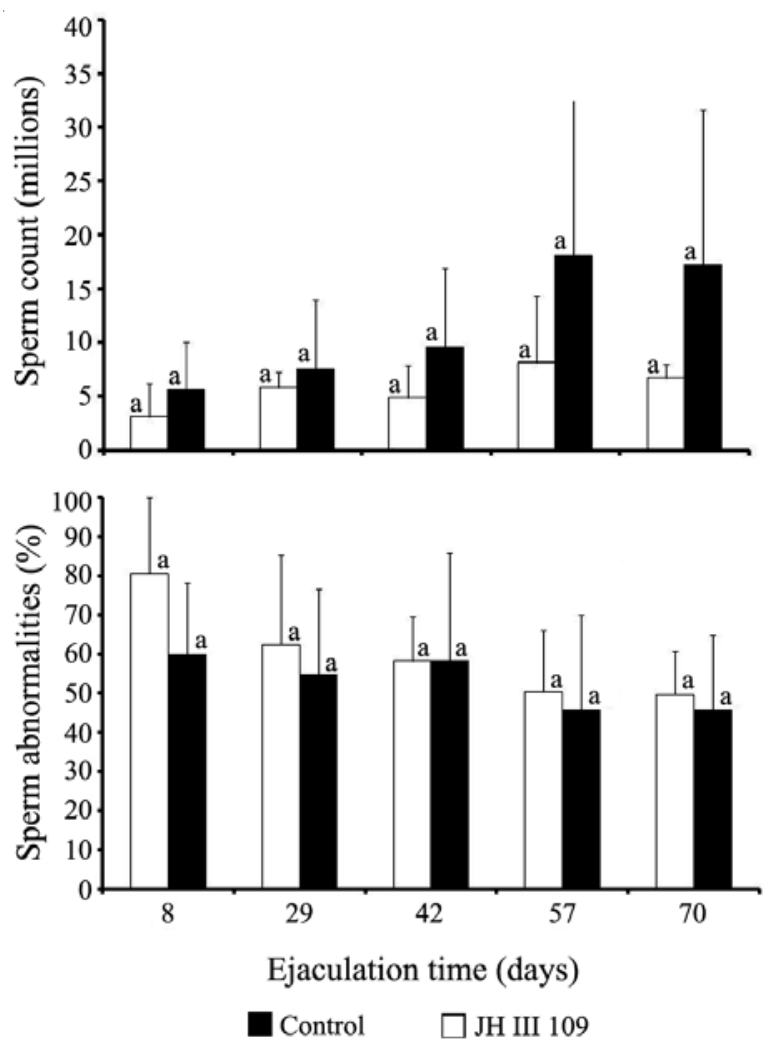

Figure 1

Evaluation of sperm counts and sperm abnormalities after successive spermatophore ejaculations for Litopenaeus vannamei injected with five doses of JH III (109 $\mathrm{ng} \mathrm{g}^{-1}$ b.w.) or vehicle solution (control group). Bars with same letters within each time sample indicate no statistically significant differences between JH-treated and control males $(P>0.05)$

Evaluación del conteo de espermatozoides y anormalidad de espermatozoides en regeneraciones sucesivas de espermatóforos de Litopenaeus vannamei inyectados con cinco dosis de HJ III (109 ng g-1 p.c.) o solución vehículo (grupo control). Barras con las mismas letras dentro de cada tiempo de muestreo indican diferencias estadísticas no significativas entre machos tratados con HJ y controles $(P>0,05)$

mortality could be induced by the amount of ethanol injected $(50 \mu \mathrm{L})$, which was quite high, compared to a previous study ( $2 \mu \mathrm{L}$; Alfaro 1996) and the JH experiment $(1 \mu \mathrm{L})$. The response in sperm counts indicates a significant improvement $(P<0.05)$ for this variable at 120 $\mathrm{ng} \mathrm{g}^{-1} \mathrm{MF}$. The response measured at $1200 \mathrm{ng} \mathrm{g}^{-1}$ was not different $(P>0.05)$ from the control group. Sperm abnormalities (Fig. 2) also indicate a positive effect of $120 \mathrm{ng} \mathrm{g}^{-1} \mathrm{MF}$ on this quality indicator $(P<0.05)$. No statistical differences $(P>0.05)$ were detected between control group and MF at $1200 \mathrm{ng} \mathrm{g}^{-1}$.
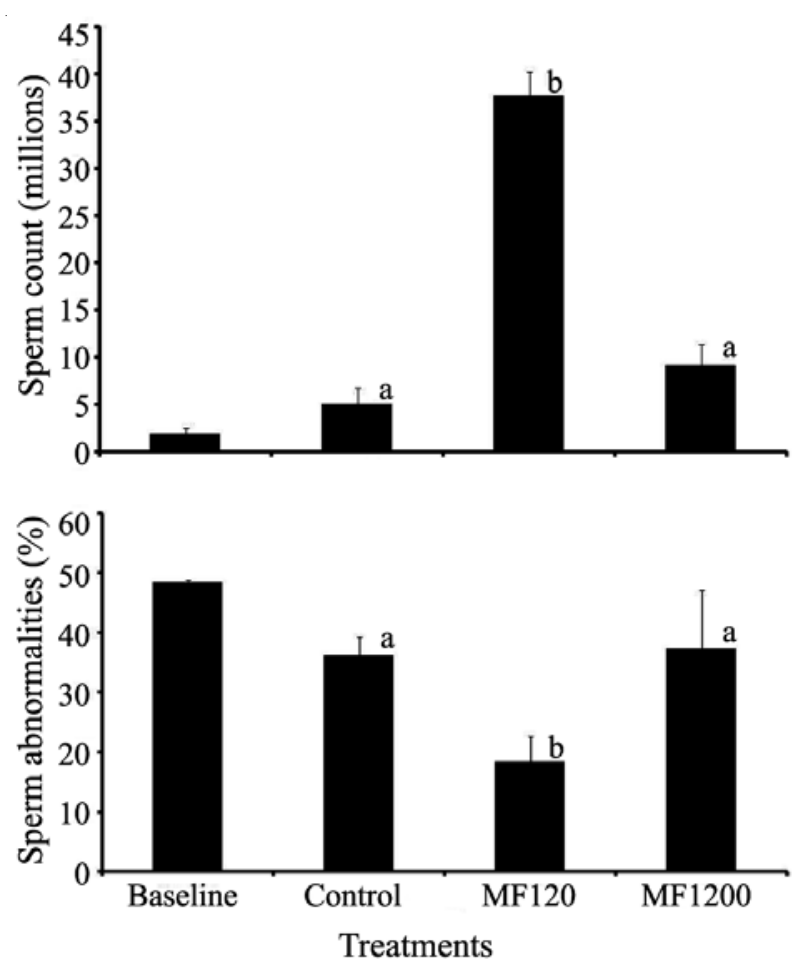

Figure 2

Evaluation of sperm counts and sperm abnormalities after a single ejaculation for Litopenaeus vannamei injected with five weekly doses of MF (120 or $1200 \mathrm{ng} \mathrm{g}^{-1}$ b.w.) or vehicle solution (control group). Baseline values were included as a reference. Bars with different letters indicate statistically significant differences between treatments $(P<0.05)$

Evaluación del conteo de espermatozoides y anormalidad de espermatozoides luego de una sola eyaculación de Litopenaeus vannamei inyectados con cinco dosis semanales de MF (120 o 1200 ng g $^{-1}$ p.c.) o solución vehículo (grupo control). Valores base fueron incluidos como referencia.

Barras con letras diferentes indican diferencias estadísticas significativas entre tratamientos $(P<0,05)$

\section{Discussion}

Artificial ejaculation under controlled reproduction conditions induced a positive effect on the quality of $L$. vannamei spermatophores as indicated by the average increase in sperm count $(P<0.05)$ and the average reduction in sperm abnormalities measured for the control group of the JH experiment. These findings agree with previous reports dealing with the positive influence of culture conditions (Alfaro \& Lozano 1993) and age on sperm quality (Ceballos-Vásquez et al. 2003). 
Vol. $43, \mathrm{~N}^{\circ} 1,2008$

The dilution of JH in saline solution was not an adequate protocol based on the hydrophobic nature of juvenoids; however, Fig. 1 shows a clear difference in response between control group and JH III group, suggesting that $\mathrm{JH}$ injections at $109 \mathrm{ng} \mathrm{g}^{-1}$ caused some negative effect on sperm count after successive ejaculations. Complementary, no effect of JH III in combination with MF was detected on oocyte growth in P. clarkii (Rodríguez et al. 2002), but in the crab Chasmagnathus granulata, JH III (diluted in crustacean saline) increased the gonadosomatic index during the prereproductive period (Zapata et al. 2003). The injection of serotonin and JH III in L. stylirostris females did not induce ovarian maturation (Alfaro et al. 2003).

Contrary to JH III, MF at a similar dose (120 $\left.\mathrm{ng} \mathrm{g}^{-1}\right)$ apparently induced a positively significant response in sperm counts and sperm abnormalities $(P<0.05)$. During the 36 days of treatment after five injections of MF at $120 \mathrm{ng} \mathrm{g}^{-1}, 27.5 \mathrm{~g}$ males improved their spermatophore quality in terms of an increase in sperm count and a decrease in sperm abnormality. However, MF at 1200 $\mathrm{ng} \mathrm{g}^{-1}\left(1.2 \mu \mathrm{g} \mathrm{g}^{-1}\right)$ did not improve significantly $(P>0.05)$ those quality parameters. Variance among replicates was low and the effect of MF was so strong that a clear and significant difference was detected regardless of small sample size; however, this statement requires further experimental confirmation using more replicates. A similar pattern was observed in the branchiopod, Triops longicaudatus (Tsukimura et al. 2006); the authors reported that low doses of MF $\left(0.75-3.8 \mu \mathrm{g} \mathrm{g}^{-1}\right)$ appeared to have an effect on fecundity, but higher doses $(10 \mu \mathrm{g} \mathrm{g}$ $\left.{ }^{1}\right)$ reduced somatic growth.

A MF dose of $120 \mathrm{ng} \mathrm{g}^{-1}$ represents around $240 \mathrm{ng}$ $\mathrm{mL}^{-1}$ hemolymph, based on the relation of $0.5 \mathrm{~mL}$ hemolymph per g b.w. (Shafir et al. 1992), or $3300 \mathrm{ng}$ male week ${ }^{-1}$. This dose is lower than the levels of MF used in P. clarkii to induce maturation (1000 - $2000 \mathrm{ng}$ female day ${ }^{-1}$; Laufer et al. 1998), and much higher than the levels measured for the reproductive male morphotype of $P$. clarkii $\left(<0.5 \mathrm{ng} \mathrm{mL}^{-1}\right)$ and the non-reproductive male type (1.3 $\mathrm{ng} \mathrm{mL}^{-1}$; Laufer et al. 2005). It is also similar to the doses of MF tested on C. quadricarinatus (4500 - 9000 ng animal week ${ }^{-1}$ ) without any effect on reproduction (Abdu et al. 2001). In eyestalk ablated females of L. emarginata hemolymph levels of MF are 2 - $3.5 \mathrm{ng} \mathrm{mL}^{-1}$ (Que-Tae et al. 1999), and the level measured in large abraded males of this species is 67.2 $\mathrm{ng} \mathrm{mL} \mathrm{m}^{-1}$ (Homola et al. 1991). These findings suggest that shrimp can not use JH III in place of MF, and provide preliminary evidence that $\mathrm{MF}$ is a reproductive hormone in penaeoid shrimps.

\section{Literature cited}

Abdu U, A Barki, I Karplus, S Barel, P Takac, G Yehezkel, H Laufer \& A Sagi. 2001. Physiological effects of methyl farnesoate and pyriproxyfen on wintering female crayfish Cherax quadricarinatus. Aquaculture 202: 163-175.

Alfaro J. 2001. Controlled reproduction of penaeid shrimp: A contribution to its improvement. Ph D Thesis, Wageningen Institute of Animal Sciences, Wageningen University, Wageningen, The Netherlands, 149 pp.

Alfaro J \& X Lozano. 1993. Development and deterioration of spermatophores in pond-reared Penaeus vannamei. Journal of the World Aquaculture Society 24(4): 522-529.

Alfaro J, G Zúñiga \& J Komen. 2003. Induction of ovarian maturation and spawning by combined treatment of serotonin and a dopamine antagonist, spiperone in Litopenaeus stylirostris and Litopenaeus vannamei. Aquaculture 236: 511-522.

Ceballos-Vásquez BP, C Rosas \& IS Racotta. 2003. Sperm quality in relation to age and weight of white shrimp Litopenaeus vannamei. Aquaculture 228: 141-151.

Downer RGH \& H Laufer. 1983. Endocrinology of insects, 707 pp. Liss, New York.

Homola E \& ES Chang. 1997. Methyl farnesoate: crustacean juvenile hormone in search of functions. Comparative Biochemistry and Physiology 117B: 347-356.

Homola E, A Sagi \& H Laufer. 1991. Relationship of claw form and exoskeleton condition to reproductive system size and methyl farnesoate in the male spider crab, Libinia emarginata. Invertebrate Reproduction and Development 20: 219-225.

Laufer H. 1992. Method for increasing crustacean larval production. United States Patent 5, 161, 481.

Laufer H \& WJ Biggers. 2001. Unifying concepts learned from methyl farnesoate for invertebrate reproduction and post-embryonic development. American Zoologist 41: 442457.

Laufer H, WJ Biggers \& JSB Ahl. 1998. Stimulation of ovarian maturation in the crayfish Procambarus clarkii by methyl farnesoate. General and Comparative Endocrinology 111: 113-118.

Laufer H, DW Borst, TA Foley \& M Landau. 1988. Ecdysteroid titres in vitellogenic Libinia emarginata. Journal of Insect Physiology 34: 615-617.

Laufer H, N Demir, X Pan, JD Stuart \& JSB Ahl. 2005. Methyl farnesoate controls adult male morphogenesis in the crayfish, Procambarus clarkii. Journal of Insect Physiology 51: 379-384.

Laufer H, J Paddon \& M Paddon. 1997. A hormone enhancing larval production in the Pacific white shrimp Penaeus vannamei. In: Alston DE, BW Green \& HC Clifford (eds), IV Symposium on Aquaculture in Central America: Focusing on shrimp and tilapia, pp. 161-162. The Latin American Chapter of the World Aquaculture Society, Tegucigalpa. 
Leung-Trujillo J \& AL Lawrence. 1985. The effect of eyestalk ablation on spermatophore and sperm quality in Penaeus vannamei. Journal of the World Mariculture Society 16: 258-266.

Ott L. 1984. An Introduction to Statistical Methods and Data Analysis, 775 pp. Duxbury Press, Boston.

Que-Tae J, H Laufer, W Biggers \& H Sung. 1999. Methyl farnesoate induced ovarian maturation in the spider crab, Libinia emarginata. Invertebrate Reproduction and Development 36: 79-85.

Rodríguez EM, LS López Greco, DA Medesani, H Laufer \& M Fingerman. 2002. Effect of methyl farnesoate, alone and in combination with other hormones, on ovarian growth of the red swamp crayfish, Procambarus clarkii, during vitellogenesis. General and Comparative Endocrinology 125: 34-40.

Rotllant G, P Takac, L Liu, GL Scott \& H Laufer. 2000. Role of ecdysteroids and methyl farnesoate in morphogenesis and terminal moult in polymorphic males of the spider crab Libinia emarginata. Aquaculture 190: 103-118.

Sagi A, E Homola \& H Laufer. 1993. Distinct reproductive types of male spider crabs Libinia emarginata differ in circulating and synthesizing methyl farnesoate. The Biological Bulletin 185: 168-173.
Shafir S, M Tom, M Ovadia \& E Lubzens. 1992. Protein, vitellogenin, and vitellin levels in the hemolymph and ovaries during ovarian development in Penaeus semisulcatus (de Haan). The Biological Bulletin 183: 394400.

Tsukimura B \& F Kamemoto. 1991. In vitro stimulation of oocytes by presumptive mandibular organ secretions in the shrimp, Penaeus vannamei. Aquaculture 92: 59-66.

Tsukimura B, WK Nelson \& CJ Linder. 2006. Inhibition of ovarian development by methyl farnesoate in the tadpole shrimp, Triops longicaudatus. Comparative Biochemistry and Physiology 144A: 135-144.

Wider M \& K Aida. 1995. Crustacean ecdysteroids and juvenoids: chemistry and physiological roles in two species of prawn, Macrobrachium rosenbergii and Penaeus japonicus. Israeli Journal of Aquaculture (Bamidgeh) 47: 129-136.

Wider M, S Okada, N Fusetani \& K Aida. 1995. Hemolymph profiles of juvenoid substances in the giant fresh water prawn Macrobrachium rosenbergii in relation to reproduction and molting. Fisheries Sciences 61: 175-176.

Zapata V, LS López Greco, D Medesani \& EM Rodríguez. 2003. Ovarian growth in the crab Chasmagnathus granulata induced by hormones and neuroregulators throughout the year. In vivo and in vitro studies. Aquaculture 224: 339-352.

Recibido el 10 de noviembre de 2006 y aceptado el 25 de enero de 2008 